\title{
Internal Marketing Communication of the Global Company in Slovak Republic
}

\author{
Jakub Michulek ${ }^{1, *}$, \\ ${ }^{1}$ University of Zilina, Faculty of Operation and Economics of Transport and Communications, \\ Univerzitna 1, 01026 Zilina, Slovakia
}

\begin{abstract}
Research background: Currently, it is constantly increasing emphasis on the satisfaction of employees in the company. One way to satisfy them through internal marketing communication. Set them training according to their needs and interests and allow them to grow their career growth. It is also the provision of information on time at the required range and especially to be up to date. As a result, employees can perform their work efficiently and work to achieve the required result that the enterprise expects. It is necessary for this internal communication in the company took place both directions for many companies. It follows that finance inserted into education of employees; it will return to a business in an even greater range. Purpose of the article: The aim of this research is to analyses the use of the tools of the communication mix in the field of internal marketing communication of the selected company.

Methods: SWOT analysis, Deduction, Comparison.

Findings \& Value added: Internal marketing communication in chosen company is on high level, according to analyzing tools and results of SWOT analysis. Added value is finding a level of internal marketing communication for company and creating some points for continuing in building quality internal marketing communication.
\end{abstract}

Keywords: Communication; Internal Marketing; Internal Marketing Communication; Tools of Internal Marketing

JEL Classification: $M 30 ; M 31 ; M 50$

\footnotetext{
* Corresponding author: jakub.michulek@stud.uniza.sk
} 


\section{Introduction}

The term of communication comes from the Latin word "communucatio", the meaning of which is to do something common, to speak, to manage or to negotiate. Communication is the process of exchanging meanings between people by using an agreed set of symbols. It is more than talking or listening (Seemann, 2018). Companies must realize that there are so many options how to create strong brand (Janoskova and Krizanova, 2017). Company can use for example green marketing (Krizanova et al., 2013), internal marketing communication, pricing policy (Krizanova and Majerová, 2013).

Internal marketing is philosophy in management which talk about employees as company's customers. Internal marketing promotes products primarily directed to employees, and when they are satisfied, then we can promote products to the customers. Despite the critical role of the internal marketing as a connection between external marketing goals and internal capabilities of company, only very few companies use internal marketing in practice (Gwinji et al., 2020). When company is developing new internal, marketing communication, it must think about the fact, that socio-economic and cultural factors are different in each corner of the globe (Civelek et al., 2020).

It is important to realize that human capital is resource, which is difficult to imitate because of the competition. This is the reason why human capital become an important factor for company's success. In this sense, is internal marketing via internal marketing communication share company's goals, vision etc. (Cruz et al., 2020). On the other side Suh and Battaglio (2021) defined internal communication as all formal and informal communication which infiltrated at all levels of a company.

Internal communication is often conceptualized as internal public relations or internal relations because of the reflection of employees as a company's (internal) stakeholders. Despite scholars highly supporting the implementation of the relationship management perspective of public relations to employee publics, there is an absence of studies on internal communication in the public relations (Jimenez-Castillo, 2016). Internal communication informs company's employees about company's brand values and activities. Such detailed information should reduce doubt about the organization, help, define and confirm organizational purpose and target on characteristic, which differentiate monitored company from other companies on the market. This type of communication can further confirm an employee's internal motivation to belong to the certain company, to sharply increase positive perceptions of a company and keep up talented and perspective staff (Herhausen, D. et al., 2020; Stefko et al., 2020). All marketing activities (external an internal) help to develop and improve brand equity (Gajanova et al., 2020). According to Balegati et al. (2019) internal communication is a tool of strategic management. Many of research confirmed relationship between internal communication and satisfaction employees, their productivity and company's results. On the other side we can't forget on fact, that excellent performance of employee must be constantly achieved by developing employee's skills, which company required (Rusli et al., 2020).

Marketing and marketing activities are changing according to demand of modern times and modern technologies (Shemyatikhina, 2020; Stefko et al., 2019). We must realise, that during last few years, the environment of internal communication notably changed, mostly by technological progress. Nowadays companies use large range of internal communication channels like face-to-face communication, printed and electronic communication and social networks. All these channels can be used effectively to share company's values and goals between employees (Verčič and Špoljarić, 2020). For companies is important to realize which tool of internal marketing communication is the most suitable for company and find out balanced mix of internal marketing communication's tools. In 2018 was created research which revealed positive correlation between company's social networks and internal communication. The result of the research is that companies should use company's social 
network to improve internal marketing communication (Alshawabkeh et al., 2018). Measuring the effectiveness of communication tools in an online environment is constantly changing environment where new marketing resources are being developed every day (Krizanova et al., 2019). In the corporate sector, there is high demand for people skilled in the existing digital technologies and able to adapt to changes in technologies quickly (Malkawi and Khayrullina, 2020).

Internal marketing communication is not affected only by new technologies, it's depends on the country, in our case SR (Krizanova, 2008). Some affect has too leadership, but if we want effective interanal marketing communication, leadership must be affective too. About area of effective leadership, made Smith (2020) research. According to these facts, it is necessary that the internal marketing communication is subject to process optimization (Williams et al., 2020) and use of Smart Devices and digitisations (Dobson-Lohman, 2020).

At Table 1. Tools of internal communication according to forms we adduce some tools about which we will talk in chapter 3 .

Table 1. Tools of internal communication according to forms.

\begin{tabular}{|c|c|c|c|}
\hline Printed Tools & Electronic Tools & Personal Forms Tools & Modern tools \\
\hline $\begin{array}{c}\text { Company's } \\
\text { magazines }\end{array}$ & $\begin{array}{c}\text { E- mail communication, } \\
\text { newsletters }\end{array}$ & All staff meeting & $\begin{array}{c}\text { Internal social medias, } \\
\text { internal campaign }\end{array}$ \\
\hline $\begin{array}{c}\text { Company's letters, } \\
\text { annual reports }\end{array}$ & Electronic newspapers, & $\begin{array}{c}\text { Consultations, internal } \\
\text { meetings }\end{array}$ & $\begin{array}{c}\text { Technological } \\
\text { platforms }\end{array}$ \\
\hline Notice- board, & Intranet, extranet, & $\begin{array}{c}\text { Conferences and } \\
\text { videoconferences }\end{array}$ & Company's chats \\
\hline
\end{tabular}

Source: Karaffova, 2016

\section{Methodology}

We used the SWOT analysis to find out if company has enough strengths to use opportunities, which is offered to company. At first, we reviewed all factors according to efficiency, where 1 is the lowest, 5 is the highest. The next step was creating weights for all factors and when we sum all weights of for example strengths, the sum must be 1 . After that we multiplied value of efficiency and weight. These values we used for creating the final SWOT matrix, when we used formula (1) and (2).

$$
\begin{aligned}
& \Sigma S-\Sigma W \\
& \Sigma O-\Sigma T
\end{aligned}
$$

\section{Results}

Thanks to interviews with employees of the company we mention factors in Table 2.

\begin{tabular}{|c|c|}
\hline Strengths & Weaknesses \\
\hline $\begin{array}{l}\text { - } \quad \text { friendly atmosphere, open communication } \\
\text { - } \quad \text { getting information early, } \\
\text { - } \quad \text { quick feedback done regularly, } \\
\text { - } \quad \text { quick transfer of information, } \\
\text { - } \quad \text { manager's active listening, } \\
\text { - } \quad \text { quick adaptations to emerging situation, }\end{array}$ & $\begin{array}{l}\text { - weak rate of manager's feedback, } \\
\text { - meeting's direction is not observed, } \\
\text { absence of recapitulation the most } \\
\text { important information at the end of } \\
\text { meeting, } \\
\text { too generally established internal } \\
\text { communication strategy. }\end{array}$ \\
\hline
\end{tabular}

Table 2. SWOT analysis matrix-Strengths and weaknesses.

Source: Own processing according to the company's internal data 
Table 3. SWOT analysis matrix- Opportunities and treats.

\begin{tabular}{|c|c|}
\hline Opportunities & Treats \\
\hline $\begin{array}{l}\text { - } \text { online trainings of soft skill characteristics for } \\
\text { future, } \\
\text { creating specific position for internal } \\
\text { marketing communication, } \\
\text { - transparency of newsletters, } \\
\text { - precise determination of the internal } \\
\text { communication strategy, } \\
\text { innovation and intranet attractiveness. }\end{array}$ & $\begin{array}{l}\text { - } \begin{array}{l}\text { abuse of a friendly atmosphere, } \\
\text { - the occurrence of mobbing or bossing } \\
\text { thanks to a friendly atmosphere, }\end{array} \\
\text { - } \begin{array}{l}\text { reluctance of the employee to work at } \\
\text { each other, }\end{array} \\
\text { - } \begin{array}{l}\text { unwillingness to incorporate into the } \\
\text { collective and cooperate, }\end{array} \\
\text { - unconstructive feedback. }\end{array}$ \\
\hline
\end{tabular}

Source: Own processing according to the company's internal data

After that we review strengths. We can see result in Table 3. The same we had done for weakness, opportunities and treats in Tables 4., 5. and 6.

Table 4. Review of identified strengths.

\begin{tabular}{|l|c|c|c|}
\hline \multicolumn{1}{|c|}{ Strength } & $\begin{array}{c}\text { Efficiency } \\
(\mathbf{1 - 5 )}\end{array}$ & $\begin{array}{c}\text { Weight } \\
\mathbf{( 0 - 1 )}\end{array}$ & $\begin{array}{c}\text { Multiplied } \\
\text { value }\end{array}$ \\
\hline Friendly atmosphere & 5 & 0.17 & 0.85 \\
\hline Getting information early & 5 & 0.21 & 1.05 \\
\hline Many of trainings and possibility of selection & 3 & 0.07 & 0.21 \\
\hline Open communication & 4 & 0.10 & 0.40 \\
\hline Quick feedback done regularly & 5 & 0.17 & 0.85 \\
\hline Quick transfer of information & 4 & 0.10 & 0.40 \\
\hline Manager's active listening & 4 & 0.11 & 0.44 \\
\hline Quick adaptations to emerging situation & 3 & 0.07 & 0.21 \\
\hline Sum & - & 1.00 & 4.41 \\
\hline
\end{tabular}

Source: Own processing according to the company's internal data

Table 5. Review of identified weaknesses.

\begin{tabular}{|l|c|c|c|}
\hline \multicolumn{1}{|c|}{ Weaknesses } & $\begin{array}{c}\text { Efficiency } \\
(\mathbf{1 - 5})\end{array}$ & $\begin{array}{c}\text { Weight } \\
\mathbf{( 0 - 1 )}\end{array}$ & $\begin{array}{c}\text { Multiplied } \\
\text { value }\end{array}$ \\
\hline Weak rate of manager's feedback & 5 & 0.35 & 1.75 \\
\hline Meeting's direction is not observed & 3 & 0.20 & 0.60 \\
\hline $\begin{array}{l}\text { Absence of recapitulation the most important information } \\
\text { at the end of meeting }\end{array}$ & 3 & 0.15 & 0.75 \\
\hline Too generally established internal communication strategy & 5 & 0.30 & 1.50 \\
\hline Sum & - & 1.00 & 4.30 \\
\hline
\end{tabular}

Source: Own processing according to the company's internal data

Table 6. Review of identified opportunities.

\begin{tabular}{|l|c|c|c|}
\hline \multicolumn{1}{|c|}{ Opportunities } & $\begin{array}{c}\text { Attraction } \\
(\mathbf{1 - 5})\end{array}$ & $\begin{array}{c}\text { Probabilities } \\
\text { of success } \\
(\mathbf{0 - 1})\end{array}$ & $\begin{array}{c}\text { Multiplied } \\
\text { value }\end{array}$ \\
\hline Online trainings of soft skill characteristics for future & 4 & 0.20 & 0.80 \\
\hline $\begin{array}{l}\text { Creating specific position for internal marketing } \\
\text { communication }\end{array}$ & 5 & 0.30 & 1.50 \\
\hline Transparency of newsletters & 3 & 0.15 & 0.45 \\
\hline $\begin{array}{l}\text { Precise determination of the internal communication } \\
\text { strategy }\end{array}$ & 5 & 0.30 & 1.50 \\
\hline Innovation and making the intranet more attractive & 3 & 0.05 & 0.15 \\
\hline Sum & - & 1.00 & 4.40 \\
\hline
\end{tabular}

Source: Own processing according to the company's internal data 
Table 7. Review of identified treats.

\begin{tabular}{|l|c|c|c|}
\hline \multicolumn{1}{|c|}{ Treats } & $\begin{array}{c}\text { Severity } \\
(\mathbf{1 - 5})\end{array}$ & $\begin{array}{c}\text { Probabilities of } \\
\text { occurrence (0-1) }\end{array}$ & $\begin{array}{c}\text { Multiplied } \\
\text { value }\end{array}$ \\
\hline $\begin{array}{l}\text { Online trainings of soft skill characteristics for } \\
\text { future }\end{array}$ & 5 & 0.30 & 1,50 \\
\hline $\begin{array}{l}\text { Creating specific position for internal } \\
\text { marketing communication }\end{array}$ & 4 & 0.26 & 1.04 \\
\hline Transparency of newsletters & 3 & 0.17 & 0.51 \\
\hline $\begin{array}{l}\text { Precise determination of the internal } \\
\text { communication strategy }\end{array}$ & 3 & 0.17 & 0.51 \\
\hline $\begin{array}{l}\text { Innovation and making the intranet more } \\
\text { attractive }\end{array}$ & 5 & 0.10 & 0.50 \\
\hline Sum & - & 1.00 & 4.06 \\
\hline
\end{tabular}

Source: Own processing according to the company's internal data

Subsequently we substituted into formulas (1) and (2). We got following results:

$$
\begin{aligned}
& \Sigma S-\Sigma W=4.41-4.30=0.11 \\
& \Sigma O-\Sigma T=4.40-4.06=0.34
\end{aligned}
$$

This results we used for creating SWOT matrix, which is shown in Figure 1. $\Sigma S-\Sigma W$ was calculated as positive number what means that we viewed it on axis $\mathrm{S} . \Sigma O-\Sigma T$ was calculated as positive number what means that we viewed it on axis 0 .

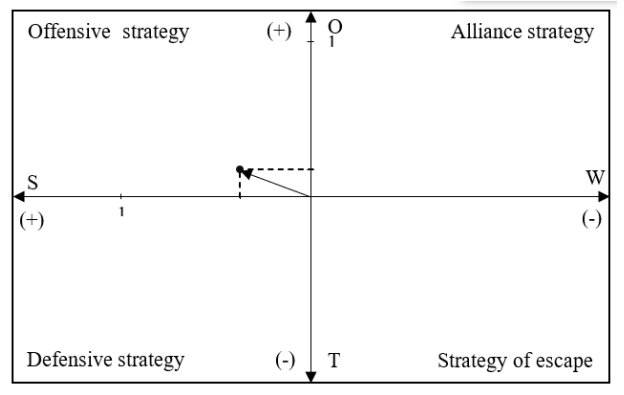

Figure 1. SWOT matrix

Source: Own processing according to the company's internal data

Result of this analysis is that company should use offensive strategy during implementing improvements.

\subsection{Analysing of internal marketing tools of chosen company}

Every year, the company doing Personal \& Development Review, which sets the goals for individual employees, their expectations and feedback. Personal \& Development Review takes place in the company from the highest positions after the lowest, where management wants to go an example of employees. The development of an employee is also evaluated, where the last year's development is evaluated, and the development will also be planned for next year. At last year's performance it is evaluated which the goals of the employee filled and which not. On this basis, future development is planned where non-fulfilled goals are moved to the following year. 
Lutherone is used as an anonymous or public opportunity for each employee to give praise employee, thank him, provide feedback to meeting, presentation etc. The company has decided for this platform as well as the influence of Covid-19 crisis to help sufficiently identify their employees and constantly improve working conditions in the enterprise and the overall climate organization. Feedback can be provided in different ways, including immediate feedback where the employee evaluates individual team members, while it can be quick feedback, welcoming new team members and the like. Employees can also use meeting feedback where they are expressed to a particular meeting. In addition to the actual evaluation of the mentioned areas, the 360 review also shows the number of total evaluations, how many of them were created in the last 30 days. It also provides a very important function, which is the evaluation of strengths and weaknesses. 360 review is shown to the employee only if the evaluations are created by at least 3 employees, so that the evaluated employee is not able to find out which evaluation was provided to him by a particular co-worker.

Company also uses intranet, enterprise website accessible, only to the company. On this website, employees can find, for example, links for applications that are used at work. At intranet employees will find links to the education system where they can choose training from the whole range of offered options. In addition, by intranet, employees can search for a variety of useful information or also know their colleagues' profiles where they find their contacts or information on what are currently working.

The company began to use MS Teams for about the year. In MS Teams, every work team has its channel which also applies to various projects and processes. This program is very popular among employees mainly due to rapid communication, call and video call options that classic e-mail communication does not provide.

The company began to use the new LinkedIn Learning platform in LinkedIn. This program has a company available around 14,000 training at different time lengths. The training offered are in different languages such as English, Spanish or various other world languages. Courses contain various hard skill courses e.g. In MS Excel or other MS Office programs, up to soft skill devoted as communications, presentation skills, various approaches to project solutions etc. Training provided by this platform for employees are made available without fees. Training takes place through videos that an employee can look at any time.

The company organizes Safety, Health \& Environment Event every year for employees, where in the period before Covid-19 crisis employees had the possibility of sports activities. Part of the event was the opportunity to participate in yoga, play football, ultimate frisbee etc. Last year, during the pandemic, this event was focused on the pandemic, where employees showed the opportunity to produce their own disinfectant gel, how to create your own mask etc.

\section{Conclusions}

Analysis of individual internal marketing communication tools showed us, high quality internal communication on which the company is based on satisfaction of employees. Company uses some of the best applications that can be used, e.g., to detect employee satisfaction, feedback via Lutherone and MS Teams on video calls, sharing individual files, and quick contact or assignment assignments. Similarly, the company informs employees every year on the results, which was achieved at Sales Meeting, where they also present them plans for the next year. At the same time, employees have large options in the development of soft and hard skills through the internal or external training system or through LinkedIn Learning platform.

Based on the results of the SWOT analysis, we would recommend the following steps to continually improve internal marketing system: 
1. The development of HR in company, where we recommended the creation of new job positions for internal marketing communication,

2. Strengthening the company's regular communication through the creation of a Communication Manual Company Employee,

3. Make more attractive company's activities to employees by creating a sports day and by the transparency of intranet and newsletters,

4. Developing communication within company, thanks to the establishment of compulsory training in the field of communication, mobbing and bossing and offering a wider spectrum online training with real lecturers.

Limitation of this research is that we made it in Slovak republic, and we research just one chosen company.

\section{References}

1. Alshawabkeh, A., Razmak, J., Qasim, A., \& Kharbat, F. F. (2018). Enhancing Intrenal Communication in Organizations Using Enterprise Social Networking. International Journal of Economics and Business Research, 15(1), 72-86.

2. Belategi, O., Gago, M., \& Egaña, T. (2019). Internal Communication in Cooperatives: La comunicación interna en las cooperativas: la percepción de las personas trabjadoras sobre la esucha y la información. Revista de Estudios ooperative 130, 9-32.

3. Civelek, M., Gajdka, K., Světlík, J., \& Vavrečka, V. (2020). Differences in the usage of online marketing and social media tools: evidence from Czech, Slovakian and Hungarian SMEs. Equilibrium. Quarterly Journal of Economics and Economic Policy, 15(3), 537563.

4. Cruz, F. G. S., Mero, N. M., \& Alcivar, M. I. L. (2020). Analysis of the Internal Marketing Dimensions in Social Economy Organizations: Study Applied to Cooperativism in Ecuador. Frontiers in psychology, 11, 580673.

5. Dobson-Lohman, E. (2020). Artificial Intelligence-based Decision-Making Algorithms, Internet of Things Smart Devices, and Real-Time Process Monitoring in Sustainable Industry 4.0. Economics, Management, and Financial Markets, 15(2), 30-36.

6. Gajanova, L., Nadanyiova, M., \& Lazaroiu, G. (2020). Specifics in Brand Value Sources of Customer in the Banking Industry from the Psychographic Point of View. Central European Business Review, 9(2), 1-18.

7. Gwinji, W. A., Chiliya, N., Chuchu, T., \& Ndoro, T. (2020). An Application of Internal Marketing for Sustainable Competitive Advantage in Johannesburg construction firms. African Journal of Business and Economic Research, 15(1), 185-202.

8. Herhausen, D., Henkel, S., \& Kipfelsberger, P. (2019). One size does not fit all: How construal fit determines the effectiveness of organizational brand communication. BRQBusiness research quarterly, 23(4), 305-318.

9. Janoskova, K., \& Krizanova, A. (2017). Comparison of selected internationally recognized brand valuation methods. Oeconomia Copernicana, 8(1), 9-110.

10. Jimenez-Castillo, D. (2016). Beyond mere information transfer: The importance of a relational approach to market- related internal communication. Journal of public relations research, 28(5-6), 268-281.

11. Karaffova, D. (2016). Interný marketing ako dôležitý prvok firemnej kultúry. Grant Journal, 5(2), 26-30. 
12. Krizanova, A., \& Majerova, J. (2013). The proposal of activities of pricing policy in the process of building and managing brand value in Slovak Republic. Advances in Intelligent Systems Research, 26, 416-419.

13. Krizanova, A., Lăzăroiu, G., Gajanova, L., Kliestikova, J., Nadanyiova, M., \& Moravcikova, D. (2019). The effectiveness of marketing communication and importance of its evaluation in an online environment. Sustainability, 11(24), 7016.

14. Krizanova, A., Majerova, J., \& Zvarikova, K. (2013). Green Marketing as a Tool of Achieving Competitive Advantage in Automotive Transport. Transport Means Proceedings of the International Conference, 45-48.

15. Malkawi, E., \& Khayrullina, M. (2021). Digital human skills from the corporate economy and business development. Ekonomicko-manazerske spektrum, 15(1), 64-74.

16. Rusli, Z., Yozani, R. E., \& Mashur, D. (2020). The mediating role of leadership on antecedents to employee performance. Polish Journal of Management Studies, 22(1), 434-451.

17. Seemann, P. (2018). Komunikačné techniky. EDIS- vydavatel'ské centrum ŽU.

18. Shemyatikhina, L., Shipitsyna, K., \& Usheva, M. (2020). Marketing management of a non-profit organization. Ekonomicko-manazerske spektrum, 14(1), 19-29.

19. Smith, M. (2020). Effective Leadership in Online Small Businesses: an Exploratory Case Study. International Journal of Entrepreneurial Knowledge, 8(2), 27-41.

20. Stefko, R., Bacik, R., Fedorko, R., Olearova, M., \& Rigelsky, M. (2019). Analysis of consumer preferences related to the use of digital devices in the e-commerce dimension. Entrepreneurship and Sustainability Issues, 7(1), 25-33.

21. Stefko, R., Fedorko, R., Bacik, R., Rigelsky, M., \& Olearova, M. (2020). Effect of service quality assessment on perception of TOP hotels in terms of sentiment polarity in the Visegrad group countries. Oeconomia Copernicana, 11(4), 721-742.

22. Suh, J., \& Battaglio, P. (2021). Assessing the Mediating Effect of Internal Communication on Strategic Human Resource Management and Perceived Performance: An Intersectoral Comparison. Review of public personnel administration, $0734371 X 21994185$.

23. Verčič, A. T., \& Špoljarić, A. (2020). Managing internal communication: How the choice of channels affects internal communication satisfaction. Public relations Review, 46(3), 101926.

24. Williams, A., Suler, P., \& Vrbka, J. (2020). Business Process Optimization, Cognitive Decision-Making Algorithms, and Artificial Intelligence Data-driven Internet of Things Systems in Sustainable Smart Manufacturing. Journal of Self-Governance and Management Economics, 8(4), 39-48.

25. Krizanova, A. (2008). The Current Possition and Perspecives of the Integrated Transport Systems in Slovak Republic. Eksploatacja I Niezawodnosc-Maintenance and Reliability, (4), 25-27. 